\title{
Problems and Countermeasures in Practical Teaching of Logistics Management Major in Higher Vocational Colleges
}

\author{
Luping Chen
}

Jiangxi Technical College of Manufacturing, Nanchang, 330095

Keywords: Higher Vocational Education, Logistics Management, practical teaching, problem, countermeasure

\begin{abstract}
Economic development must be based on the circulation of commodities, while logistics is a complex industry which integrates transportation, storage, handling, distribution and information processing of commodities, directly relating to the development of economy. Especially in today's rapid development of electronic commerce industry, logistics industry is needed by the public and the demand for personnel engaged in logistics industry is also greatly increasing. Nowadays, when all good and bad mixed together, many people in the logistics industry thirst for benefits but idle away, which leads the good development of logistics industry to be hindered to a certain extent. Therefore, the matter of training a large number of high-quality logistics management professionals must be put on the agenda. However, in higher vocational colleges, to establish a new talent training system will take a lot of time, so giving full play to the role of practical teaching has become a shortcut to train logistics management professionals. This paper mainly aims at the problems existing in the practical teaching of logistics management major in higher vocational colleges and related countermeasures are briefly analyzed and summarized.
\end{abstract}

\section{Introduction}

Compared with other universities, higher vocational colleges pay more attention to the cultivation of applied talents, and Logistics Management Major requires students to have a strong practical ability. It can be said that with scientific and effective practical teaching, professional training level of higher vocational colleges will be guaranteed. However, at present, related practical teaching of Logistics Management Major in higher vocational colleges has encountered various difficulties, since either teachers' teaching methods are wrong or students' actual operation ability is not enough. The following is a brief description of problems in practical teaching of Logistics Management Major in higher vocational colleges.

\section{Problems Existing in Practical Teaching of Logistics Management Major in Higher Vocational Colleges}

Logistics Management is a kind of compound service industry which develops and flourishes gradually with the continuous improvement of people's quality of life, putting higher professional skill requirements and practical operation ability requirements for post-respondents. The most important step to train this kind of applied talents is the practical teaching link. Only by strengthening practical teaching and a large number of practical operation training can students of Logistics Management fully understand theoretical knowledge in books and handle practical problems calmly so as to adapt to the requirements of market.

However, it is regrettable that practical teaching has not been embodied in the teaching of Logistics Management Major in most vocational colleges in China, and most colleges still follow the traditional teaching mode which stresses theory but neglect practice. A reasonable practical teaching process should include four basic links: cognitive practice, on-campus practice, off-campus practice and graduation design. However, many teachers in higher vocational colleges have to give up two important links of cognitive practice and on-campus practice because they do not have hardware facilities which should be provided by universities, therefore, students have lost 
many practical opportunities, and the contents of textbooks has also suffered an irreparable impact. Moreover, in the compilation of Logistics Management professional materials, practical teaching method should be considered in the actual teaching. Therefore, contents of textbooks are more systematic and more general, which has a greater hindrance to those students who have not experienced cognitive practice and on-campus training.

On the one hand, there is insufficient investment in all aspects of site construction for students majoring in Logistics Management, not because higher vocational colleges have no awareness of building sites, but because they are also limited by funds. Whether it is pre-planning of the actual site construction or purchasing equipment to the later regular maintenance, large amount of money is required, which is very difficult for the vast majority of Higher Vocational colleges. Of course, there are many institutions purchasing a set of simulation software to make up for this shortage. Although the current science and technology are capable of making this set of simulation software achieve a very similar degree, false after all is false. The application of simulation software greatly reduces students' sense of experience, and the interaction with teachers will be reduced, let alone their improvement of operational ability.

On the other hand, the training base outside colleges is single and not professional enough. As the government attaches great importance to the development of vocational education and advocates cooperation between universities and enterprises, many colleges will seize this opportunity to cooperate with enterprises to use the operating laboratory. However, without protection of relevant policy provided by the state, colleges are also affected by geographical location and conflict of interests and other aspects. Few suitable enterprises, which makes vocational colleges have no choice, push students to reluctantly accept the existing practical conditions. Obviously, these are unable to meet the requirements to improve Logistics professional students' practical operation ability. Of course, there are many vocational colleges willing to pay cost to set up their own training centers outside colleges, but most of these training centers are only available for visits. Those can be actually operated by students is limited to some small facilities with low cost.

One of the most important figures to judge whether a college has a bright future is the teaching faculty, and the decisive factor to decide whether the Logistics major of a college will develop is the level of practical teachers' skills. Teaching team with high quality and high technology plays an important role in guaranteeing the quality of teaching. Affected by various aspects, China's Logistics education started late and Logistics personnel is not enough. Many teachers in higher vocational colleges come from finance, management and other majors, whose professional qualities can be imagined, resulting in irreparable educational defects to students.

Society is developing and progressing all the time, and the world economy tends to be more and more globalized. The development of network technology brings a lot of benefits to the Logistics industry, so it promotes the development of Logistics industry. Meanwhile, Logistics is a necessary industry which is developing all over the world, whose development has further promoted the development of global economy. Therefore, it is indisputable to increase the training of Logistics Management professionals and teachers who train these talents must have higher professional quality. It can be seen that, it is urgent to increase the support for Logistics Management education.

\section{Several Suggestions for Practical Teaching of Logistics Management Major in Higher Vocational Colleges}

Influenced by various factors, independent majors of Logistics Management are set relatively late in China. Many excellent educational concepts of related majors came from foreign countries. Therefore, in the practical teaching of Logistics Management, it is required to pay attention to the teaching of theory and carry forward excellent Logistics Management concepts with Chinese characteristics. Of course, it is better to learn the desirability of foreign related concepts, and combine the actual situation of their own ideas with excellent theoretical knowledge at home and abroad as a whole to create a more diversified concept theory. Some examples show that it is difficult to teach the theoretical basis of Logistics Management to students only by paying attention to practical teaching. Therefore, practical teaching should be based on the theoretical knowledge 
already conveyed to students. The combination of these two can give full play to their respective values (On the one hand, it is necessary to give full play to practical teaching to improve students' practical ability. On the other hand, theoretical knowledge can cultivate students' professional connotation.). In this way, students are able to avoid some low-level mistakes in the actual operation.

Coincidentally, although the practical teaching of Logistics Management is more difficult than that of most other disciplines, it still needs innovation just like all disciplines. However, at present, the innovation of practical teaching in our country is not enough, while the rapid development of economy requires Logistics Management personnel to keep pace with the times, therefore, the innovation of practical teaching is indispensable. In fact, teaching essence of Logistics Management is still the combination of theory and practice. Logistics Management Major in higher vocational colleges is a highly practical subject. Only by innovating teaching practice can the implementation of practical teaching achieve the state of "twice the results with half the effort". In the actual teaching, as professional Logistics Management educators, we should pay attention to cultivate students' subjective initiative and innovative consciousness, so that they can better mobilize their own learning cells.

Paying attention to the subjectivity of practical teaching in Logistics Management can help students understand more clearly the specific details of Logistics Management, so that teachers' teaching can get due results as well as help students learn better. The main purpose of practical teaching of Logistics Management Major is to help students better understand knowledge points and basic skills. It is not difficult to find that if we use more intuitive teaching methods, it will be more conducive to the presentation of teaching contents. But in the process of intuitive teaching, we need to firstly pay attention to the timing of visual presentation in class. Only by presenting relevant pictures, videos or audio to students at the appropriate time according to teaching progress, can we maximize the actual value of the contents presented. Secondly, teachers are required to learn to apply the principle of practical applicability (that is, when students learn Logistics Management, they are able to continuously explore future development in combination with their own professional experience). For example, Logistics, as a complex but systematic project, involves resources and many other aspects. To arrange all students to experience in enterprises, whether for vocational colleges or enterprises, is a very difficult thing. So, if a simulation of teaching can be established, students can feel the state of their work subjectively, which can lay a foundation for their future work. Through this experience, students are able to clearly learn and grasp each link and specific operation method, and at the same time, they will have sufficient time to speculate and think over the details they see repeatedly. This kind of guiding teaching mode has been adopted by most higher vocational colleges and is likely to become the mainstream of practical teaching of Logistics Management Major in the future.

\section{Conclusion}

To sum up, practical teaching of Logistics Management Major in higher vocational colleges is a very difficult task, which requires a lot of manpower, material and financial resources. It is not only inseparable from the support of relevant national policies, but also needs the cooperation of government departments and enterprises, excellent Logistics Management professional teachers, as well as students' active learning consciousness. Only in this way can the practical teaching of Logistics Management Major in higher vocational colleges be done well. As the educators of Logistics Management Major in Higher Vocational Colleges in the new era, we should be student-centered, start from improving teaching ability, combine with the actual situation in teaching and keep exploring and trying, so as to help students learn Logistics Management Major well and help our country to train more professional talents of Logistics Management.

\section{References}

[1] Wang Xiurong, Liu Zhaojun. Collaborative Construction of Practical Teaching System of 
Logistics Management Major in Higher Vocational Colleges Based on Double Creative Ability Training [J]. Logistics Science and Technology, 2018,41(04): 134-136.

[2] Qin Xiaohui, Tian Huixing. Problems and Countermeasures of Practical Teaching Mode of "3+1" Innovation and Entrepreneurship of Logistics Management Major --- Taking Guangxi University for Nationalities as an example [J]. China Market, 2018 (01): 213-214.

[3] Song Lihua. Analysis of Current Status and Countermeasure of Practical Teaching of Logistics Management Major in Higher Vocational College--Taking Shanxi Communications Vocational and Technical College as an example [J]. Logistics Engineering and Management, 2016,38(12): 176-178.

[4] Cao Yiping. Problem Analysis and Countermeasure Discussion on Practical Teaching Base Construction of Logistics Management Major [J]. Economic and Trade Practice, 2016 (06): 112.

[5] Luo Da. Problems and Countermeasures in the Construction of Practical Teaching Base of Logistics Management Major: Taking South China Institute of Software Engineering.GU as An Example [J]. China Management Informatization, 2015,18(16): 253-254.

[6] Yang Xiulian. Problems and Countermeasures in Practical Teaching of Logistics Major in Higher Vocational Colleges [J]. Journal of Chifeng University (Natural Science Edition), 2012, 28 (22): 196-197.

[7] Cai Wei. On the Problems and Countermeasures of Practical Teaching of Logistics Management Major in Higher Vocational Colleges [J]. Management and Technology of small and Medium-sized Enterprises (Early Issue), 2011(07):229.

[8] Research Group of "Theoretical Research and Practice on the Construction of Practical Teaching Model of Logistics Management Major in Higher Vocational Colleges”, Ju Hongxia. Analysis of the Current Status and Countermeasure of Practical Teaching of Logistics Management Major in Higher Vocational Colleges in China [J]. Journal of Liuzhou Vocational and Technical College, 2007 (04): 58-61. 